\title{
Serum Progesterone Levels in Mares in Winter and During Transitional Periods
}

\author{
By E. Koskinen ${ }^{1}$, M. Huhtinen ${ }^{1}$ and T. Katila ${ }^{2}$ \\ ${ }^{1}$ Agrıcultural Research Centre, Equine Research, Ypäjà, and ${ }^{2}$ Unıversity of Helsinkı, Faculty of Veterınary Med- \\ ıcıne, Anımal Reproduction, Saarı, Finland.
}

\begin{abstract}
Koskinen E., M. Huhtinen and T. Katila: Serum progesterone levels in mares in winter and during transitional periods. Acta vet. scand. 1996, 37, 409-414. - Weekly blood samples were collected for serum progesterone determınation from 68 mares durIng the period from September 1990 to June 1991 A total of 78\% (53/68) of the mares became anoestrous: $88 \%(15 / 17)$ of mares with foals and $75 \%(38 / 51)$ of dry mares $(p=0323)$. Six mares of the 15 which continued cycling showed persistent corpus luteum for 77 days on average (range 42-106 days). Anoestrus began between September and February, most frequently in December, and ended in January to June, most frequently in March. Mares with foal at foot became anoestrous in 2 separate groups, in September and in December Anoestrus ended most frequently in February in foaled mares. The mares with foals differed significantly from the other mares both at onset $(p=0.0084)$ and end $(p=0.0218)$ of anoestrus

However, the effect of the stable was also significant at onset $(p=0.0386)$ and end $(p=0.0170)$ of anoestrus. Since all mares with foals were kept in one stable and dry mares in 4 different stables, the effect of stable and possible differing lightıng conditions cannot be separated from the foal effect. The length of anoestrus was on average 101 days for lactatıng mares and 95 days for dry mares $(p=06691)$. In foaled mares its length was on average 159 days in mares which had entered anoestrus as early as in September-October and 62 days in mares entering anoestrus in December $(p=0001)$. The effects of breed and age were not significant in any of the parameters
\end{abstract}

season; anoestrus.

\section{Introduction}

The mare is a long-day seasonally polyoestrous animal with a period of sexual rest in winter called the nonovulatory season or winter anoestrus (Allen 1985). The incidence of ovulation in the northern hemisphere is minimal or absent during winter, increases during spring, is maximal during summer and decreases in autumn (Ginther 1974, Wesson \& Ginther 1981, Allen 1985). In the southern hemisphere, the annual distribution of ovulations is similar across the seasons (Osborne 1966, van Niekerk 1967, Dowsett et al. 1993). Mares also show a sea- sonal reproductive pattern near the equator, although the maximum variation in photoperiod throughout the year is only $2 \mathrm{~h}$ (Saltiel et al. 1982). The most northern or cold climate studies on cyclicity of the mare come from Finland, latitude $61^{\circ} \mathrm{N}$ (Koskinen \& Katila 1991) and from Iceland, latitude $63^{\circ} \mathrm{N}$ (Dyrmundsson 1993).

The earliest reports on the incidence of ovulation were slaughter-house studies based on the finding of corpora lutea (CL) (Arthur 1958, Osborne 1966, Wesson \& Ginther 1981). Teasing and rectal palpation have been other means to 
study cyclicity (Ginther 1974). In free-ranging ponies and horses, start of ovarian activity has been determined from the birth dates of foals (Keiper \& Houpt 1984, Dyrmundsson 1993). Lately, serum progesterone determination (Koskinen \& Katila 1991) and ultrasonography (King et al. 1993) have become the most commonly used methods in studying ovarian function.

Not all mares have inactive ovaries in winter. Some $10 \%$ to $15 \%$ cycle throughout the year and a similar proportion of mares exhibit spontaneous prolongation of CL (Allen 1985, King et al. 1993). The vernal transition in spring has been an area of active research, but very little research has been done on the transition from the ovulatory season to the anovulatory season, apparently because no breeding activity takes place during this time. In the first study published (Ginther 1974), the last ovulations of the season occurred at the earliest in August and latest in December. The majority of these pony mares in Wisconsin were anoestrous in November. Snyder et al. (1979) showed that failure of ovulation at the onset of the anovulatory season was due to the absence of an adequate ovulatory LH surge and final growth of a preovulatory follicle. In Illinois, USA, (latitude $40^{\circ} \mathrm{N}$ ), mares start to enter anoestrus in November and peak numbers occur in January (King et al. 1993). In autumnal cycles, the follicular phase is shortened, follicular size is increased, and oestradiol production by the follicles diminishes relative to follicular size (Weedman et al. 1993).

We have previously studied seasonal effects on ovarian function of mares in Finland: onset of luteal activity in spring (Koskinen \& Katila 1991), the time of first post-partum ovulation (Koskinen 1991) and the effect of artificial light (Koskinen et al. 1991). The purpose of this study was to examine the period of vernal transition in autumn in the northern climate of Finland.

\section{Materials and methods}

The study was carried out at the Equine Research Station in southern Finland, latitude $61^{\circ} \mathrm{N}$, from September 1990 to June 1991. The day length there is $>18 \mathrm{~h}$ in mid-summer and $<6 \mathrm{~h}$ in mid-winter.

The mares were American Standardbreds $(n=8)$, warm-blood riding horses $(n=20)$ and Finnhorses $(n=40)$, altogether 68 mares, of which 17 were lactating and 51 dry mares, average age $7.0 \pm 3.5$ years (range 2-16). The mares were kept in individual boxes in 4 stables: 22 mares in the brood mare stable and 17,17 , and 12 mares in the other 3 stables, which were for animals in training. The mares either were trained daily or had paddock exercise for 2 to $4 \mathrm{~h}$. The lights were on in all stables during the daily activities, from 6 to $6: 30$ a.m. until 6 to $6: 30$ p.m. In the training stables, the lights were sometimes on until 10 p.m.

Weekly blood samples were collected from the jugular vein. Progesterone was determined in serum samples by direct RIA (Spectria* Progesterone [ $\left.{ }^{125} \mathrm{I}\right]$ Radioimmunoassay, Orion Diagnostica, Finland). A progesterone concentration of $>10 \mathrm{nmol} / 1$ (Koskinen et al. 1990) was considered an indication of luteal activity. All mares were cycling at the beginning of the study, as shown by their progesterone concentration of $>10 \mathrm{nmol} / 1$ in the first, second or third weekly blood sample. If a concentration of $>10$ $\mathrm{nmol} / 1$ was recorded in at least 4 subsequent samples, it was considered prolonged luteal function. When the progesterone concentration was $<10 \mathrm{nmol} / 1$ in at least 4 subsequent samples, a period of anoestrus was recorded. One mare had no progesterone rise during the entire follow-up period after a period of ovarian inactivity in winter. However, because she was in oestrus and conceived in June, her rise in progesterone was recorded for the month of June. Statistical analysis of the frequencies was performed with the Chi-square test. Analysis of 


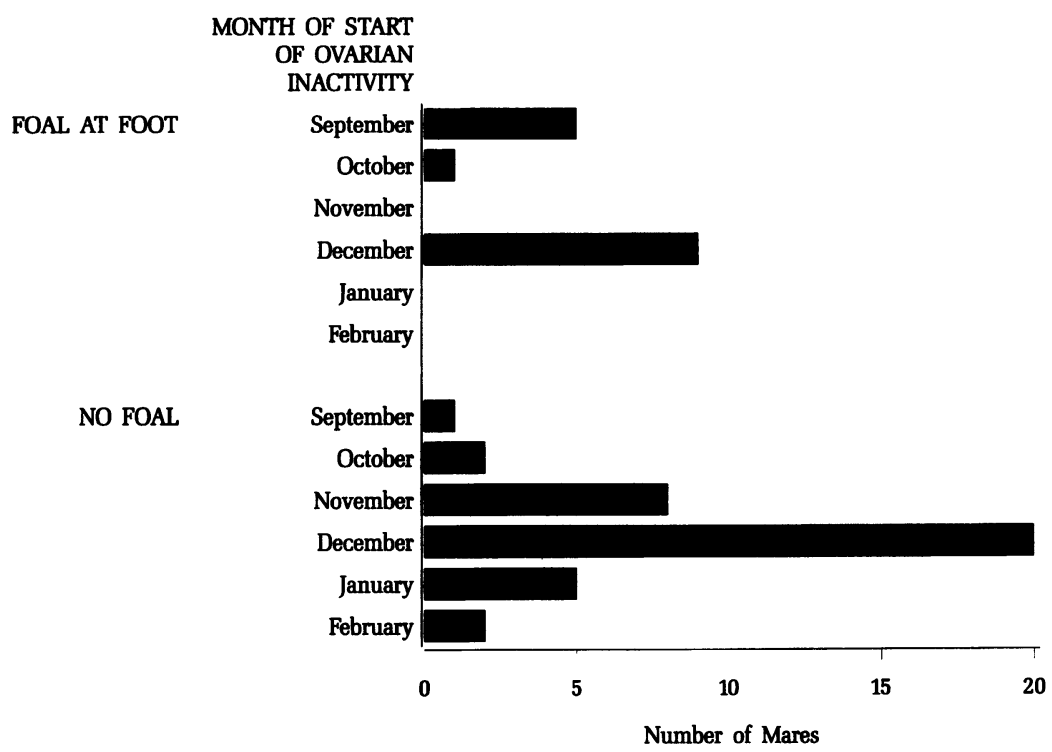

Figure 1. The onset of ovarian winter inactivity in mares with a foal at foot and in dry mares.

variance was used to determine the significance of difference in the onset, end and length of the low progesterone phase. Independent variables were lactation status (lactating vs nonlactating), breed (Finnhorse vs non-Finnhorse), age ( $\leq 7$ years vs $>7$ years) and the stable (brood-marestable vs non-brood-mare-stable) where the mare was kept.

\section{Results}

Anoestrus occurred in 78\% (53/68) of mares: in $88 \%(15 / 17)$ of the mares with foals and in $75 \%$ $(38 / 51)$ of the nonfoaling mares $(p=0.323)$. Cyclical progesterone secretion throughout the winter was demonstrated in $22 \%$ (15/68) of the mares, and 6 of these 15 showed in addition prolonged luteal function which lasted, on average, 77 days (range 42-106). One mare had 2 such periods. In 2 mares, concentrations of progesterone during dioestrus dropped for two months to a $50 \%$ lower level.
Anoestrus began between September and February, most frequently in December (Fig. 1). Mares with foal at foot entered anoestrus in 2 separate groups, in September-October and in December. The effect of lactation/foal on time of onset was statistically significant $(p=0.0084)$, but the effect of stable was also significant $(p=0.0386)$. All mares with foals were housed in the same brood-mare stable.

Anoestrus ended between January and June, most frequently in February in foaled mares and in March in dry mares (Fig. 2). The effect of lactation/foal was statistically significant $(p=0.0218)$, but the effect of stable was also significant $(p=0.0170)$. Length of anoestrus ranged from 28 to 176 days, on average, 101 days in lactating mares and 95 days in dry mares $(p=0.6691)$. The effect of stable was not significant $(p=0.9620)$. In foaled mares the length of anoestrus was 159 days (range 133176) in mares which had already entered anoestrus in September-October and 62 days (range 


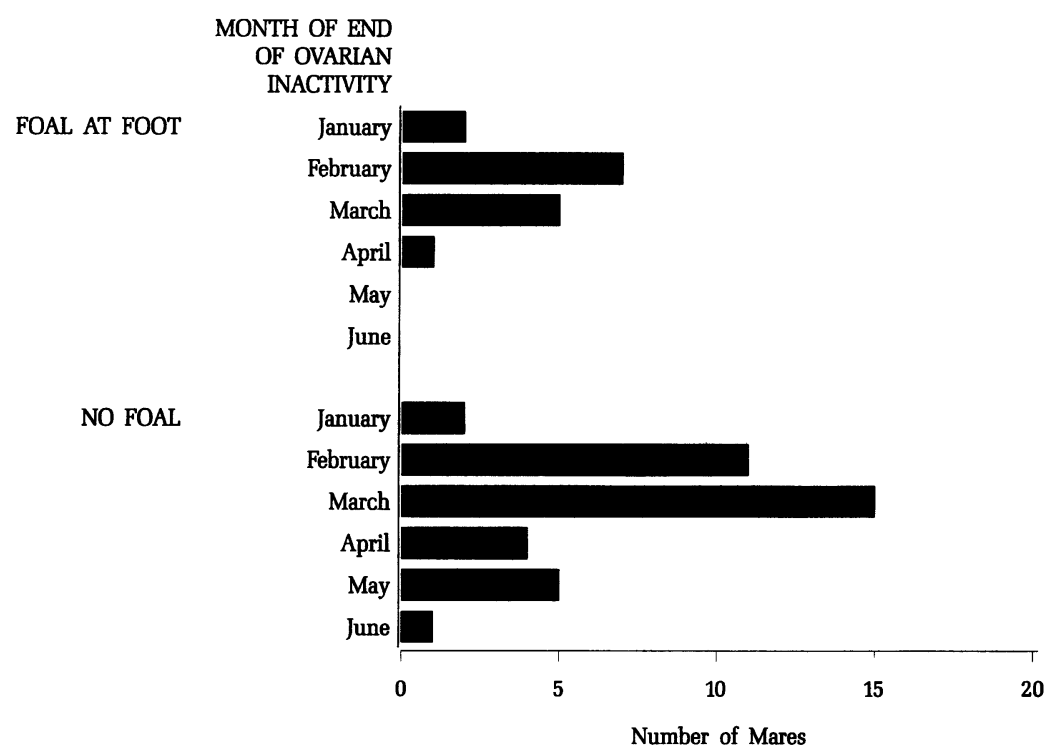

Figure 2. The end of ovarian winter inactivity in mares which had foaled the previous year and in nonfoaling mares.

33-91) in mares which had entered anoestrus in December $(p=0.001)$.

The effects of breed and age of the mares on time of onset $(p=0.4501$ and 0.2027 , resp.), end $(p=0.5492$ and 0.4151 , resp.), and length ( $p=0.4501$ and 0.2027 , resp.) of anoestrus were not statistically significant.

\section{Discussion}

In slaughtered pony mares, the lowest incidences of corpora lutea were found in January (9\%), February (11\%), March (13\%), April (17\%) and December (25\%) (Wesson \& Ginther 1981). In Ginther's (1974) study on pony mares, all mares were acyclic in January, February and March, 1 of 14 (7\%) ovulated in April and in December. Of 18 light horse mares, 2 (11\%) continued to cycle throughout the winter (King et al. 1993). This figure is similar to that of our study: $12 \%$ of the mares with foals continued to cycle. Palmer \& Driancourt (1983) observed winter anoestrus in all mares that had foaled in summer $(\mathrm{n}=13)$, whereas only 3 of 10 maiden or barren mares entered anoestrus. We have previously shown that racing mares or mares in training continue to cycle more often than brood mares $(40 \%$ vs $0 \%)$ (Koskinen \& Katila 1991). Palmer (1978) has stated that pony mares more often exhibit anoestrus than do horse mares. In our study, although one might have expected that the more primitive Finnhorse breed would have longer lasting ovarian inactivity, there were no interbreed differences. In a previous report (Koskinen \& Katila 1991), Finnhorses started to cycle later than the warmbloods.

It has been mentioned that the variation among mares in the day of termination of their breeding season tends to be greater than the variation in day of onset (Ginther 1974, Sharp \& Davis 1993), but this was not verified in the present study. The onset of anoestrus as well as the onset of cyclical activity showed considerable variation among the mares, both events being 
distributed over a 6 month period. King et al. (1993) concluded that anoestrus is achieved later than previously reported. We were also surprised that the majority of our mares were still cycling in November and the last ones became anoestrous as late as in January.

In our study some lactating mares entered anoestrus markedly earlier than did other lactating mares or dry mares. Nutritional balance may be one explanatory factor for this difference; this needs further research. Although the mares with foals seemed to differ from the other mares in the onset of anoestrus, this could not be differentiated from the effect of stabling, because all mares with foals were housed in one stable. The daily activities - and consequently the time when the stables were artificially lighted - did not continue in the brood mare stable as late as in the stables for mares in training.

Ovarian activity started earlier in spring in the mares with previously weaned foals. It is not clear wether their earlier onset of ovarian inactivity had an effect on this timing. Another explanation could be the different lighting conditions in autumn: lactating mares were exposed to short days in autumn. It is possible that lights were on in the training stables for too long. It has been shown that the mare needs a period of short days in autumn to become sensitive to light stimulation in spring (Guillaume et al. 1995).

It has been thought that $10-15 \%$ of mares remain in prolonged dioestrus throughout the winter due to persistence of luteal tissue from the ovulation in the preceding autumn (Allen 1985). King et al. (1993) pointed out that luteal function is altered during winter; in their study, 3 mares experienced persistent $\mathrm{CL}$ followed by anoestrus, and they had additional cases of prolonged CL which were followed by one or $2 \mathrm{cy}$ cles of normal length prior to entry into anoestrus. In our study, 6 mares exhibited persistent
CL for variable lengths of time (from 42 to 106 days), and this began at random during the entire examination period.

The results reported here indicate that breeding is often possible late in autumn; lactating mares can, however, start anoestrus soon after summer. The anoestrous state during winter is mainly due to ovarian inactivity, but in some mares it is due to prolonged luteal function. As compared to the previously published literature on anoestrus, our results did not differ greatly, perhaps indicating that breed and latitude do not have a very marked effect. The findings of these kinds of studies are, however, difficult to interpret or compare, since the management of mares, lighting, exercise, feeding and previous reproductive history may affect the study outcome.

\section{References}

Allen WR: Practical control of anoestrus in Thoroughbred broodmares. In. Ellendorff F, Ellsaesser $F$ (eds.) Endocrine causes of seasonal and lactational anestrus in farm anımals. Martinus N1jhoff Publishers, Dordrecht, 1985, 98-107.

Arthur GH An analysis of the reproductive function of mares based on post-mortem examination. Vet. Rec., 1958, 70, 682-686.

Dowsett KF, Knott LM, Woodward RA, Bodero DAV . Seasonal variation in the estrous cycle of mares in the subtropics. Thenogenology, 1993, 39, 631653.

Dyrmundsson OR Reproduction of Icelandic horses with special reference to seasonal sexual activity. Horse breeding and production in cold climatic regions, Reykjavík, Iceland, 11.-13.8.1993.

Ginther $O J \cdot$ Occurrence of anestrus, estrus, diestrus, and ovulation over a 12-month period in mares. Amer. J vet. Res., 1974, 35, 1173-1179.

Gullaume D, Arnaud G, Camillo F, Duchamp G, Palmer E. Effect of melatonın implants on reproductive status of mares. Biol. Reprod. Mono, 1995, 1, 435-442.

Kelper R, Houpt $K$. Reproduction in feral horses: An eight-year study. Amer. J. vet. Res., 1984, 45, 991-995.

King SS, Neumann KR, Nequin LG, Weedman BJ. 
Time of onset and ovarian state prior to entry into winter anestrus. J. eq. vet. Sci., 1993, 13, 512515.

Koskinen E, Lindeberg H, Kuntsi H, Katila T: Milk and serum progesterone levels in mares after ovulation. Acta vet. scand., 1990, 31, 441-444.

Koskinen E: Post-partum ovarian activity in Finnhorse mares with special reference to seasonal effects. Acta vet. scand., 1991, 32, 313-318.

Koskinen E, Katila T: Onset of luteal activity in nonfoaling mares during the early breeding season in Finland. Acta vet. scand., 1991, 32, 319-325.

Koskinen E, Kurki E, Katila T: Onset of luteal activity in foaling and seasonally anoestrus mares treated with artificial light. Acta vet. scand., 1991, 32, 307-312.

van Niekerk $\mathrm{CH}$ : Pattern of the estrous cycle of mares. I. The breeding season. J. S. Afr. vet. med. Ass., 1967, 38, 295-298.

Osborne VE: An analysis of the pattern of ovulation as it occurs in the annual reproductive cycle of the mare in Australia. Aust. vet. J., 1966, 42, 149154.

Palmer E: Control of the oestrous cycle of the mare. J. Reprod. Fert., 1978, 54, 495-505.

Palmer E, MA Driancourt: Some interactions of season of foaling, photopenod and ovarian activity in the equine. Livestock Prod. Sci., 1983, 10, 197-210.

Saltiel A, Calderon A, Garcia N, Hurley DP: Ovarian activity in the mare between latitude $15^{\circ}$ and $22^{\circ}$ N. J. Reprod. Fert., Suppl. 32, 1982, 261-267.

Sharp DC, Davis SD: Vernal transition. In: McKinnon AO, Voss JL (eds.). Equine reproduction, Lea \& Febiger, 1993, 133-143.

Snyder DA, Turner DD, Miller KF, Garcia MC, Ginther OJ: Follicular and gonadotrophic changes during transition from ovulatory to anovulatory seasons. J. Reprod. Fert., Suppl. 27, 1979, 95-101.

Weedman BJ, King SS, Neumann KR, Nequin LG:
Comparison of circulating estradiol-17ß and folliculogenesis during the breeding season, autumn transition and anestrus in the mare. J. eq. vet. Sci., 1993, 13, 502-505.

Wesson JA, Ginther OJ: Influence of season and age on reproductive activity in pony mares on the basis of a slaughterhouse survey. J. Anim. Sci., $1981,52,119-129$.

\section{Sammanfattning \\ Progesteronkoncentratıonen $i$ blodserum hos ston som indikator på vinteranöstrus början och slut.}

Progesteronkoncentrationen i blodserum uppmättes en gång per vecka under perioden september-juni hos 68 ston. Av samtliga ston inträdde $78 \%(53 / 68)$ i anöstrus: $88 \%(15 / 17)$ av stona som hade föl vid s1dan och $75 \%(38 / 51)$ av icke lakterande $(p=0.323)$. Sex av 15 ston, som inte gick in i vinteranöstrus, hade en persisterande corpus luteum under i genomsnitt 77 dagar (variation 42-106 d). Anöstrus påbörjade under perioden september-februar, oftast i december och upphörde mellan januari och junı, oftast i mars. Fölston inledde sin anöstrusperiod antingen i september eller i december. Anöstrus avslutades oftast i februarı hos ston som fölat. Gruppen fölston skilde sıg signifikant från övriga ston både beträffande inledning och avslutning av anöstrus $(p=0.0084$ och 0.0218$)$. Emellertıd visade sig effekten av stallet vara signifikant $(p=0.0386$ respektıve 0.0170$)$. Eftersom fölstona hölls i ett stall och övriga ston var fördelade på 4 olika stall kunde effekten av stall och möjligtvis olika ljusförhållanden inte skiljas från effekten av föl vid sidan. Anöstrus varade 1 medeltal 101 dagar hos digivande ston och 195 dagar hos ston slutat laktera. Hos fölston som inträtt $i$ anöstrus i september-october varade anöstrus i genomsnitt 159 dagar och hos ston som inträtt $i$ anöstrus 1 december 62 dagar. Stonas ras och ålder hade ingen signifikant effekt på de analyserade parametrarna.

(Received May 17, 1996; accepted June 24, 1996).

Reprints may be obtained from: E. Koskınen, Agricultural Research Centre, Equine Research, Varsanojantie 63, SF-32100 Ypäjä, Finland. Fax: +358 2760 2260, e-mail: Erkki.Koskinen@MTT.FI. 